\title{
Morpho-anatomical, physiological and biochemical changes in rubber tree seeds
}

\author{
GENAINA A. DE SOUZA ${ }^{1}$, DENISE C.F.S. DIAS ${ }^{2}$, THALINE M. PIMENTA ${ }^{1}$, AMANDA Á. \\ CARDOSO $^{1}$, RAQUEL M.O. PIRES ${ }^{2}$, ANTÔNIO P. ALVARENGA ${ }^{3}$ and EDGARD A.T. PÍCOLI ${ }^{1}$ \\ ${ }^{1}$ Departamento de Biologia Vegetal, Universidade Federal de Viçosa, Avenida Ph \\ Rolfs, s/n, Campus Universitário, 36570-000 Viçosa, MG, Brazil \\ ${ }^{2}$ Departamento de Fitotecnia, Universidade Federal de Viçosa, Avenida Ph Rolfs, \\ s/n, Campus Universitário, 36570-000 Viçosa, MG, Brazil \\ ${ }^{3}$ Empresa de Pesquisa Agropecuária de Minas Gerais, Avenida Ph Rolfs, s/n, Vila \\ Gianetti, Campus Universitário, Casa 46, 36570-000 Viçosa, MG, Brazil
}

Manuscript received on May 8, 2017; accepted for publication on December 20, 2017

\begin{abstract}
The physical, physiological and biochemical changes during the development until the dispersal of rubber tree seeds were evaluated with the purpose of estimating the point at physiological maturity. A total of 30 plants were selected at different points in a commercial planting area and had their flowers marked during the anthesis and every 15 days after marking. Fruits and seeds were collected for analysis of moisture content, dry matter, diameter and length. Details of the anatomy ultra-structure of the seeds were evaluated. The seed emergence, emergency speed index, heat resistant proteins and oxidative stress enzymes were examined. It was observed that fruits reached maximum size at 120 days after anthesis and seeds at 150 days. The seeds acquired germination capacity after 150 days. At 175 days, they presented the highest percentage of dry matter and lowest moisture, in addition to a higher percentage of germination and vigor. Therefore, it was possible to conclude that the physiological maturity of the rubber tree seeds occurs at 175 days after anthesis, and coincides with its maximum physiological quality. At 175 and 180 days postanthesis, there is a greater expression of heat resistant proteins as well as low molecular weight and greater oxidative stress enzyme activity.
\end{abstract}

Key words: germination, oxidative stress enzymes, physiological maturity, seeds development.

\section{INTRODUCTION}

The recalcitrant characteristic of the seeds implies a rapid loss of their viability, especially when dehydrated to a water content of less than $30 \%$ (Bonome et al. 2011). This behavior makes it difficult to store the seeds in the medium and

Correspondence to: Genaina Aparecida de Souza

E-mail: genainasouza@yahoo.com.br long term, causing drawbacks to the production of seedlings. This production is performed by grafting a productive clone in the shoot with the seed being used as a scion graft.

Low longevity makes it difficult to install nursery plants, because seeds lose their viability quickly. This is because the recalcitrance of the rubber tree seeds generates restriction of its supply in suitable periods of sowing. In addition 
to augmenting the production costs, the rapid loss of seed viability during the interval between harvesting and sowing requires seeds at figures that reach, commonly, four times higher than the necessary amount for conventional crops in order to support the demand for seedling production.

Seed harvest takes place during the dehiscence of the fruit, when they are dispersed and little is known about the process of development and maturation of these seeds, especially after the period when they reach physiological maturity. At this moment, the plant ceases the translocation of assimilation to the seed and, in general, the physiological quality reaches its maximum, providing a high percentage of germination and vigor (Mata et al. 2013). This information can contribute to enable reaching greater periods of seed storage.

During seed formation, physical and physiological changes occur that characterize the development phases in which they are, such as the following: color change, seed coat opacity, water and dry matter content, germination capacity, ability to produce normal seedlings (Borges et al. 2006) and chemical composition (Mata et al. 2013). These changes can be used to estimate the Seed Physiological Maturity Point (SPMP) that is associated with the condition of greater germination and vigor (Matheus et al. 2011, Borges et al. 2006).

The maturation process can be predicted by estimating the SPMP of a given seed. However, it is necessary to evaluate the physiological and biochemical changes that occur during development in association to climatic conditions in which the seeds were formed. In addition to the previously mentioned characteristics, changes in water content, reserve compound content and increase in the expression of heat resistant proteins are evaluated (Walters at al. 2013, Kalemba and Pukacka 2012). In relation to rubber tree seeds, information about SPMP will be relevant to obtain seeds of high physiological quality and to guarantee the seedling production system, since the seeds are available shortly before the beginning of winter, which may compromise the seedlings development.

The kinetics of moisture contents, dry matter, starch content, proteins, lipids, electrical conductivity, among other characteristics can provide information related to a seed's maturation (Bonome et al. 2011) in addition to cytological and anatomical changes, such as changes in the number and size of vacuoles (Pavithra et al. 2014). Along with that, the cell division commonly observed in the embryo axis is associated with the germination of recalcitrant seeds soon after dispersion is observed (Caccere et al. 2013), which in this context would suggest that a longer germination time would lead to seed decease.

Therefore, the objective of this study was to describe the kinetics of dry matter and moisture contents, the reserves content and the morphological, physiological and anatomical characteristics of the seed to delimit and define safe indications of the physiological maturity point of rubber tree seeds.

\section{MATERIALS AND METHODS}

The study was carried out at the experimental farm of Agricultural Research Company of Minas Gerais - EPAMIG - municipality of Oratórios, MG, Brazil, in a commercial plantation of rubber tree Hevea brasiliensis, with an altitude of $530 \mathrm{~m}$. The inflorescences were marked and identified with tape-like markers, impermeable during flower opening in order to monitor the number of days after anthesis (DAA). During the period between the flower opening and fruit dispersion, samples were collected every 15 days, (except between 90 and 120 DAA). Flowers were picked in different positions of the canopy in a total of 30 plants, taken at random in the planting area. For each of the evaluated periods, the following tests and determinations were performed: 


\section{MORPHOPHYSIOLOGICAL EVALUATIONS}

Length (L) and diameter (D) of fruits and seeds: determined every 15 days until 175 DAA, starting from 15 DAA (fruits), and 45 DAA (seeds). Measurements were performed on 30 fruits (not removed from the plant) and 90 seeds extracted from the fruits, with a digital caliper. Moisture content of seeds and fruits (M): determined by the oven method at $105^{\circ} \mathrm{C}$, for $24 \mathrm{~h}$ (Brasil 2009), using four replications composed of 10 seeds and three fruits, broken open to facilitate drying. The results were expressed as a percentage. Dry seed mass (DM): determined using four replications of 10 seeds that were kept in an oven at $70{ }^{\circ} \mathrm{C}$ until obtaining a constant weight. Electrical conductivity (EC): obtained with four replications of 10 seeds for each period. Seeds of each repetition were weighed to an accurate of $0.001 \mathrm{~g}$ and placed in plastic cups containing $200 \mathrm{ml}$ of distilled water, remaining for a period of $24 \mathrm{~h}$ at a constant temperature of $25{ }^{\circ} \mathrm{C}$. The EC of solution containing the seeds was measured with a mass conductivity meter, obtained by dividing the conductivity value $(\mu \mathrm{S}$ $\mathrm{cm}^{-1}$ ), deducted from the conductivity value of the distilled water, by the mass $(\mathrm{g})$ of the 10 seeds. Its value expressed in $\mu \mathrm{S} \mathrm{cm}^{-1} \mathrm{~g}^{-1}$, the final result was obtained by the average of the values determined in each repetition. Emergency or Germination test $(\mathrm{G})$ : performed in a greenhouse with four replications of 50 seeds, sown at $1.0 \mathrm{~cm}$ depth in trays containing moistened sand, replacement of water when necessary. Emergency speed index (ESI): performed in conjunction with the emergency test. Daily counts of emerging seedlings (shoots with 1 $\mathrm{cm}$ or more) were made until stabilization and the ESI was calculated according to Maguire (1962).

\section{BIOCHEMICAL EVALUATIONS}

Oxidative stress enzymes (fruits and seeds) analysis: in order to do this analysis, crude enzymatic extracts were used to determine the activity for the for catalase (CAT), peroxidase (POX), ascorbate peroxidase (APX) and superoxide dismutase (SOD). For this purpose, $0.3 \mathrm{~g}$ seeds or fruits were macerated, adding $2 \mathrm{~mL}$ of a homogenization medium, consisting of a potassium phosphate buffer $0.1 \mathrm{M}, \mathrm{pH} 6.8$, ethylenediaminetetraacetic acid (EDTA) $0.1 \mathrm{mM}$, phenylmethylsulfonic fluoride (PMSF) $1 \mathrm{mM}$ and polyvinylpyrrolidone (PVPP) 1\% (w/v) (Peixoto et al. 1999), followed by centrifugation at $12.000 \mathrm{xg}$ for $15 \mathrm{~min}$ at $4{ }^{\circ} \mathrm{C}$. Determination of superoxide dismutase activity (SOD): $30 \mu \mathrm{L}$ of crude enzyme extract was used in $2.97 \mathrm{~mL}$ of the reaction medium consisting of sodium phosphate buffer $50 \mathrm{mM}, \mathrm{pH} 7.8$, containing methionine $13 \mathrm{mM}$, P-nitro blue tetrazolium (NBT) $75 \mu \mathrm{M}$, EDTA $0.1 \mathrm{mM}$ and riboflavin $2 \mu \mathrm{M}$ (Del Longo et al. 1993). The reaction was conducted at $25^{\circ} \mathrm{C}$ in a reaction chamber under illumination of a fluorescence lamp at $15 \mathrm{~W}$, kept inside a box covered with aluminum foil. After $5 \mathrm{~min}$ of exposure to light, illumination was interrupted and the blue formazan, produced by the photoreduction of the NBT, was determined by measuring the absorbance at $560 \mathrm{~nm}$. The control was measured under the same conditions, though without the presence of light, before measuring the absorbance (Giannopolitis and Riens 1977). A unit of SOD was defined as the amount of enzyme required to inhibit in $50 \%$ of the NBT photoreduction (Beauchamp and Fridovich 1971). Determination of catalase activity (CAT): $100 \mu \mathrm{L}$ of crude enzyme extract was added to 2.9 $\mathrm{mL}$ of the reaction medium, consisting of potassium phosphate buffer $50 \mathrm{mM}$, pH 7.0 and $\mathrm{H}_{2} \mathrm{O}_{2} 12.5 \mathrm{mM}$ (Havir and McHale 1987). During the first minute of the reaction, maintained at $25{ }^{\circ} \mathrm{C}$, the decrease in absorbance at $240 \mathrm{~nm}$ was measured. The enzymatic activity was calculated using the molar extinction coefficient of $36 \mathrm{M}^{-1} \mathrm{~cm}^{-1}$ (Anderson et al. 1995) and expressed in $\mu$ mol. $\mathrm{min}^{-1} \mathrm{mg}^{-1}$ protein. Peroxidase activity (POX): was determined by the addition of $100 \mu \mathrm{L}$ of crude enzyme extract to 2.9 $\mathrm{mL}$ of the reaction medium consisting of potassium 
phosphate buffer $25 \mathrm{mM}$, pH 6.8, pyrogallol 20 $\mathrm{mM}$ and hydrogen peroxide $20 \mathrm{mM}$ (Kare and Mishra 1976). The increase in absorbance during the first minute of reaction at $420 \mathrm{~nm}$ at $25{ }^{\circ} \mathrm{C}$ determined the production of purpurogalin. The enzymatic activity was calculated using the molar extinction coefficient of $2.47 \mathrm{mM} \mathrm{L}^{-1} \mathrm{~cm}^{-1}$ (Chance and Maehley 1955) and expressed in the $\mu \mathrm{mol}$. $\min ^{-1} \cdot \mathrm{mg}^{-1}$ protein. Ascorbate peroxidase activity (APX): determined by the addition of $100 \mu \mathrm{L}$ of crude enzyme extract to $2.9 \mathrm{~mL}$ of the reaction medium consisting of ascorbic acid $0.8 \mathrm{mM}$ and $\mathrm{H}_{2} \mathrm{O}_{2} 1.0 \mathrm{mM}$ in potassium phosphate buffer 50 $\mathrm{mM}, \mathrm{pH}$ 6.0. The decrease in absorbance at $290 \mathrm{~nm}$ at $25{ }^{\circ} \mathrm{C}$ during the first minute of reaction (Nakano and Asada 1981, Koshiba 1993) was observed. The enzymatic activity was calculated using the molar extinction coefficient of $2.8 \mathrm{mM}^{-1} \mathrm{~cm}^{-1}$ (Nakano and Asada 1981) and expressed in the $\mu \mathrm{mol} \mathrm{min} \mathrm{mg}^{-1}$ protein. Heat-resistant proteins: the electrophoresis profile method was used, wherein $0.3 \mathrm{~g}$ of embryos extracted from the seeds harvested at 135, 150, 165, 175,180 DAA were macerated and added to $2 \mathrm{~mL}$ of the homogenization medium, potassium phosphate buffer $0.1 \mathrm{mM}, \mathrm{pH} 6.8$, ethylenediaminetetraacetic acid (EDTA) $0.1 \mathrm{mM}$, phenylmethylsulfonic fluoride (PMSF) $1 \mathrm{mM}$ and polyvinylpyrrolidone (PVPP) 1\% (w/v) (Peixoto et al. 1999), followed by centrifugation at $12.000 \mathrm{xg}$ for $15 \mathrm{~min}$ at $4{ }^{\circ} \mathrm{C}$. Subsequently, this was incubated at $85{ }^{\circ} \mathrm{C}$ and centrifuged again. The supernatant was collected and used to perform the electrophoresis. $16 \mu \mathrm{L}$ of the sample (extract + sample buffer) was applied by a channel in the polyacrylamide gel SDS-PAGE $12.5 \%$ (separator gel). The electrophoretic run was performed at $100 \mathrm{~V}$ for $4 \mathrm{~h}$ and the gels were stained during $12 \mathrm{~h}$ in Coomassie Blue Brilliant at $0.05 \%$ and then bleached in $10 \%$ acetic acid solution. Lipids quantification: the extraction and quantification of the lipid content were carried out in a Soxhlet type apparatus, by the method of cold extraction with petroleum ether for $24 \mathrm{~h}$, according to Silva (1990).

\section{ANATOMICAL AND HISTOCHEMICAL EVALUATIONS}

Light microscopy: seed were placed in FAA in $50 \%$ ethanol for $48 \mathrm{~h}$ under a vacuum and after that, stored in 70\% ethanol (Johansen 1940). Subsequently, they were dehydrated with an ethanol series and embedded in methacrylate (Historesin, Leica Instruments, Heidelberg, Germany). Sections were made with an automatic advanced rotary microtome (model RM2155, Leica Microsystems Inc., Deerfield, USA), at $5 \mu \mathrm{m}$ thickness and mounted onto glass slides. Sections were stained with toluidine blue $\mathrm{pH} 4.0$ for 8 min for structural characterization (O'Brien and Mccully 1981), with xylidine ponceau (XP) for total proteins (O'Brien and McCully 1981) and Lugol for starch detection (Johansen 1940). For lipids detection, the seeds placed in FAA50 were sectioned transversely to $40 \mu \mathrm{m}$ with a cryomicrotome. Sections of the different stages of development were stained with Sudan black B (Pearse 1972). The controls for histochemistry consisted of mounted sample sections without staining. The images were taken with a photomicroscope (model AX70 TRF, Olympus Optical, Tokyo, Japan) with the U-PHOTO system, coupled with a digital camera (model AxionCan, Carl Zeiss, Gena, Germany) and a microcomputer. Ten samples were evaluated for each maturation period, represented respectively with 2 slides per sample and 10 slices per slide. Scanning Electron Microscopy (SEM): endosperm and embryo samples were immersed in a Karnovsky modification (paraformaldehyde $2 \%$, glutaraldehyde $2.5 \%, \mathrm{CaCb} 25 \mathrm{mg} / \mathrm{ml}$ ) for a minimum period of $24 \mathrm{~h}$. Subsequently, they were washed in a cacodylate buffer three times and postplaced in aqueous solution of $1 \%$ osmium tetroxide for $4 \mathrm{~h}$ at room temperature. After this time, they were washed three times in distilled water and then, 
dehydrated using the critical-point drying method in acetone $(25,50,75,90$ and $100 \%$ three times). After that, they were taken to the critical point apparatus for drying, coated with gold and then mounted on stubs for metallization. The specimens were observed in the Scanning Electron Microscope LEO Evo 40, located in the Laboratory of Electron Microscopy and Ultra-Structural Analysis at the Phytopathology Department - UFLA. Transmission electron microscopy (TEM): after dehydration in acetone, samples were infiltrated with Spurr resin, initially at $30 \%$ resin for $8 \mathrm{~h}$ and then at $70 \%$ resin. After $12 \mathrm{~h}$, the samples were passed twice through $100 \%$ resin for $24 \mathrm{~h}$ each time, the material placed in suitable molds and polymerized in a $70{ }^{\circ} \mathrm{C}$ oven for $48 \mathrm{~h}$. After ultramicrotomy, the ultrafine sections were placed on copper grids and then stained with uranyl acetate and lead citrate. Specimen observation was performed with a Zeiss EM 109 transmission electronic microscope in the Laboratory of Electronic Microscopy and Ultra-Structural Analysis at the Phytopathology Department - UFLA.

Descriptive statistics were used for the characteristics related to fruit and seed development. The data obtained for germination and ESI tests were submitted to variance analysis and Tukey's test at a $5 \%$ probability level.

\section{RESULTS}

\section{MORPHOPHYSIOLOGICAL AND BIOCHEMICAL EVALUATIONS}

Length (L) and diameter (D) of the fruits increased from 15 days after anthesis (DAA) until 120 days, when the maximum values were reached (Fig. 1a). There was a gradual increase in $\mathrm{D}$ and $\mathrm{L}$ of the seeds, from the beginning of the evaluation at 45 DAA to 150 DAA, with a greater increase in length (Fig. 1b). Dry matter (DM) content of fruits and seeds remained stable until about 90 DAA, increasing sharply after $150 \mathrm{DAA}$, with a maximum at 175 DAA. The moisture content (M), initially high in seeds $(73 \%)$ and fruits $(80 \%)$, remained high until 90 DAA, with significant reduction from this point, reaching the lowest values at 175 DAA, i.e., $46 \%$ (seeds) and 25\% (fruits). It was also possible to verify that the period of reduction in the seeds' water content coincided with the period of greatest dry mass accumulation at 150, 165 and 175 DAA (Fig. 1c, d). The seeds acquired considerable germination capacity from 150 DAA onward (Fig. $1 \mathrm{e}, \mathrm{f})$. In this period, there was an increase in germination and ESI with maximum values at 175 DAA, values similar to those obtained for seeds already dispersed (from 180 DAA). In periods prior to $150 \mathrm{DAA}$, germination was negligible or less than $20 \%$.

The increase in seed size was accompanied by changes in the color, brightness and opacity of the seed coat. Initially, the tegument presented color in white/cream shades (60 and 90 DAA) (Fig. 2b), followed by a yellowish color (Fig. 2c) and the beginning of surface color variation (120 DAA) (Fig. 2d) and then incomplete color surface variation around $75 \%$ of the seed surface (Fig. 2e). From 150 DAA onwards, the entire surface became a color range of brown and beige shades (Fig. 2e, f). The embryo became visible to the naked eye at 120 DAA. The observed morphology at 150 DAA shows that the embryos were in the cotyledonary stage, wherein a smaller increase of the hypocotylradicle axis was verified in comparison to the expansion of cotyledons, which practically doubled in area until the 175 DAA (Fig. 2i, j). In this way, it was verified that in this species the embryo develops after the establishment of endosperm development (Fig. 2). The fruit growth was gradual, and the coloration changed from an intense green to a slightly yellowish green until 120 DAA (Fig. 2a). After that, the fruit lost its green tones and changed to shades of gray and brown.

Electrical conductivity (EC) is a vigor test that can be associated with seed physiological quality. 

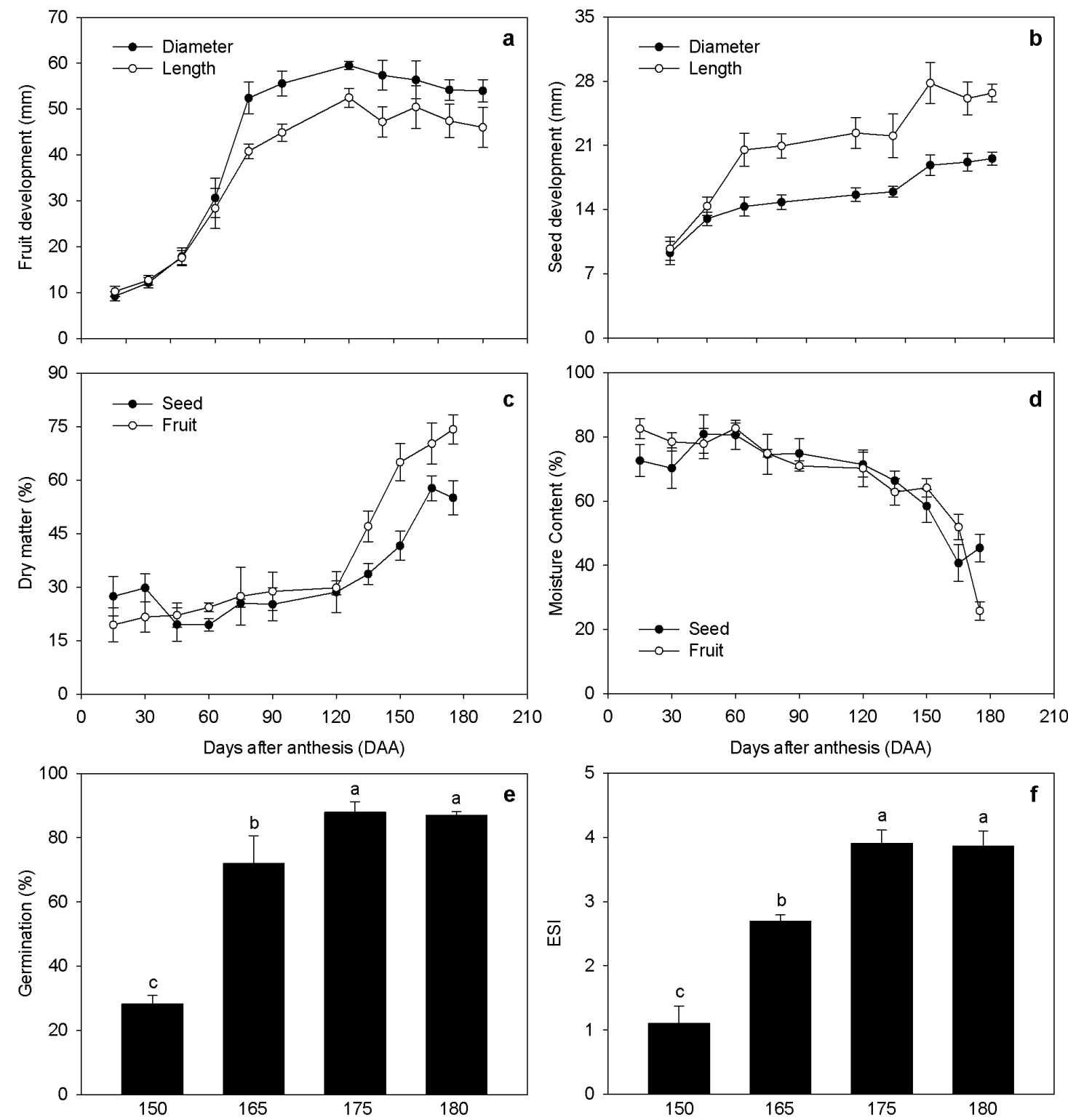

Figure 1 - Growth curve for fruits (a) and seeds (b), of Hevea brasiliensis L., seeds harvested at 150, 165, 175 and collected at 180 DAA. For fruits $n=30$, seeds $n=90 \pm$ standard error. Dry matter and moisture content of fruits (c) and seeds (d), $\mathrm{n}=5 \pm$ standard error; Germination/emergence (e) and emergency speed index (ESI) (f), $\mathrm{n}=5$. Means followed by the same letter do not differ by Tukey's test at a $5 \%$ probability.

It was observed that during the period in which germination occurred, there was a continuous reduction in EC, from approximately 6.6 to 2.3 $\mu \mathrm{s}^{-1} \mathrm{~cm}^{-1} \mathrm{~g}$ in the last period evaluated, $180 \mathrm{DAA}$, in seeds already dispersed. In addition to the EC reduction, there was accumulation of heat resistant proteins (HRP) at the end of maturation in the rubber tree seeds. It was possible to observe an increase in the intensity of bands from the 165 DAA in comparison to the previous periods. At 175 DAA the pattern was similar to the 180 DAA, mainly in the proteins with a molecular weight between 21 and $45 \mathrm{KDa}$ and $66 \mathrm{KDa}$ (Fig. 3).

Another parameter widely used to give information about the seed's physiological quality is the activity of oxidative stress enzymes, such 


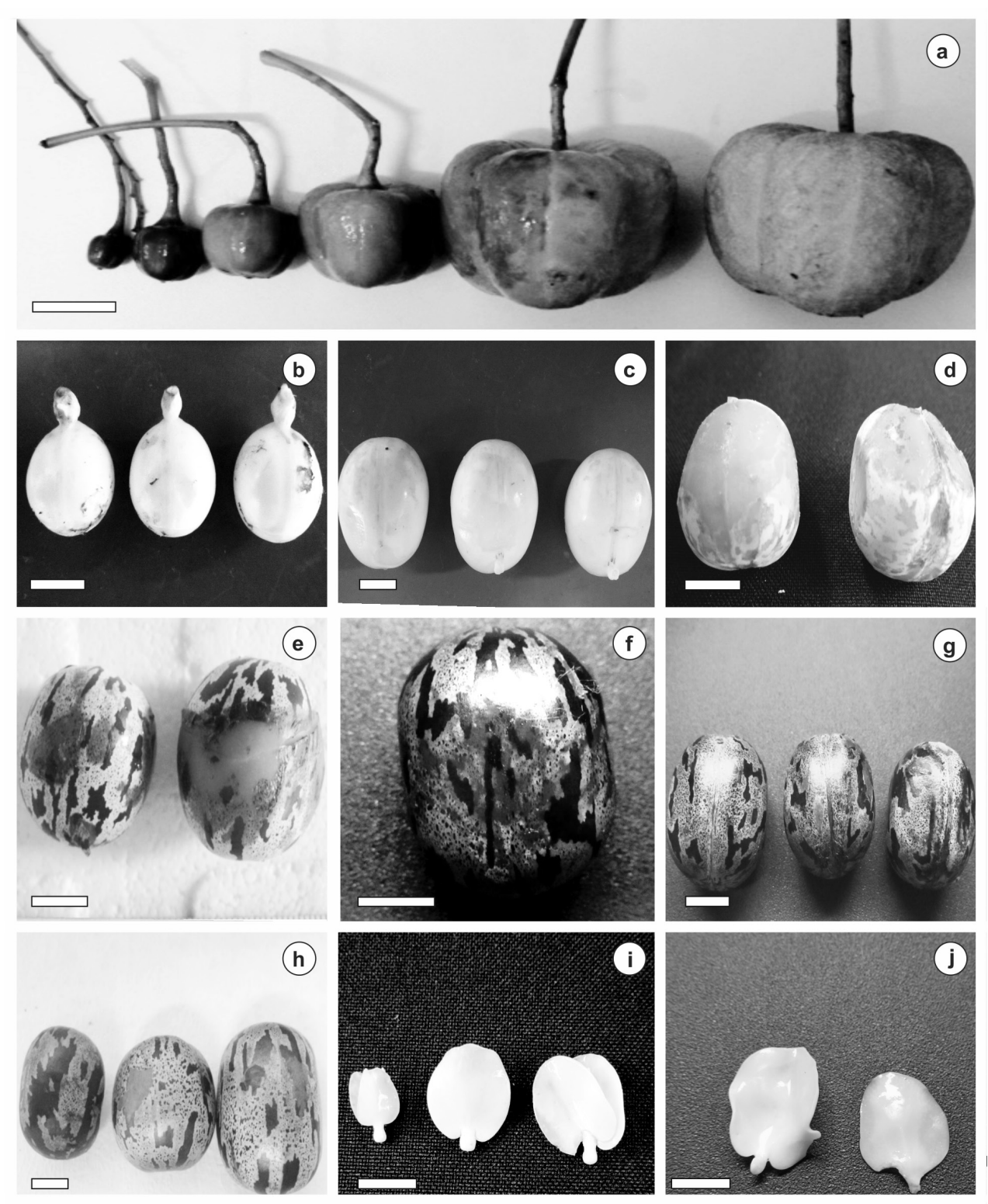

Figure 2 - Hevea brasiliensis L. fruit, during the development at 15, 30, 60, 75, 90 and 120 DAA (a) and seeds at 60 DAA (b), 90 DAA (c), 120 DAA (d), 150 DAA (e), 165 DAA (f), 175 DAA (g) and after dispersion (h). Embryo at 150, 165 and 175 DAA (i) and embryo after the dispersion (j). Bars $=1 \mathrm{~cm}$.

as SOD, CAT, POX and APX. Higher enzymatic activity was observed at the beginning and at the end of seed development. On the other hand, for the fruit, the activity of these enzymes was lower at the end of maturation (Fig. 4). The APX values are initially higher in the seeds, decreasing over time. There was higher CAT, POX and APX activity in the seeds than in the fruits, which suggests higher metabolic activity in the seeds, whereas the SOD activity was similar. An increase in SOD activity in the seeds was observed at 135 DAA. Regarding total proteins, in the rubber tree fruit there was slight variation during development. In the seeds, increase was observed starting after 120 DAA. SOD activity ranges in mg amount, from approximately $6.31 \mathrm{mg}$ $\mathrm{g}^{-1} \mathrm{FM}$, at this 120 DAA to $21.59 \mathrm{mg} \mathrm{g}^{-1} \mathrm{FM}$ at 175 


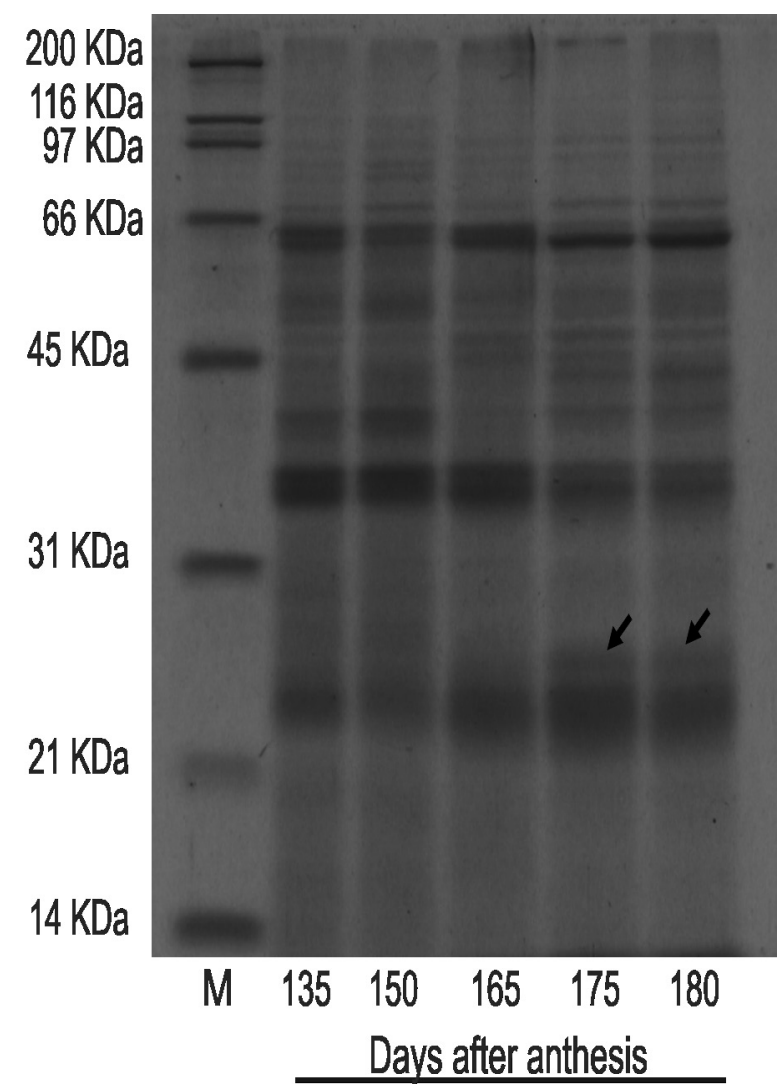

Figure 3 - Electrophoretic profile of low molecular weight heat shock proteins (smHRPs) in embryonic axes of rubber tree seeds harvested at 135, 150, 165, 175 and 180 days after anthesis. M - molecular marker. The arrows indicate the similarity among the seeds immediately before the dispersion and recently dispersed.

DAA (Fig. 4e). The same pattern was observed for starch deposition, which for seeds generally increased throughout development. However, after 135 DAA there was a large increase in storage content of seeds (Fig. 4f). This accumulation begins in the endosperm and discretely in the embryo and, at the end of the development of the seed, intense accumulation in both structures was observed.

\section{Anatomical and histochemical changes during seed development}

With light microscopy, it was observed that rubber tree endosperm is abundant, whitish and oily, wherein the presence of lipids was confirmed by Sudan test (Fig. 5g-i). Protein bodies are stained positively by Xylidine Ponceau, which dyed the protein bodies red (Fig. 5m-o). Endosperm cells have a small number of vacuoles which, nevertheless, occupy a large part of the intracellular space, mainly at 175 DAA (Fig. 5e), primarily in the endosperm and in cotyledons. Was also observed an increase in the size of the cells during development, which was more evident in the endosperm (Fig. 5ae). Furthermore, there was a large increase in the cell number in the initial phase, evident by the cell division (Fig. 5a, b, e, f).

In SEM images, we observed deposition of reserve compounds (Fig. 5g-o). After the initial period, it is observed that in addition to the reserve deposition, there was an increase in size of the storage bodies, seen throughout the development, starting from 15 DAA, where the storage bodies were previously discrete, but from 150 DAA until 175 DAA an increase in the size of the storage compounds was observed in SEM and TEM images (Figs. 5j-1, 6b, d, f).

This increase in number and size for starch can be confirmed by light microscopy images at 150, 165 and 175 DAA (Fig. 5j-1), proteins (Fig. 5m, n) and lipids (Fig. 5g, h). In the final development stages, it was possible to observe coalescence of the protein bodies at 150 and 175 DAA (Fig. 5o) and lipid consumption, inferred by the smaller number of lipid bodies (Fig. 5i). Reduction in lipid concentration was also verified in the biochemical analyzes. At 15 DAA the seed had about $5 \%$ of lipids, with an expressive increase up to 150 DAA, reaching about $33.5 \%$ and at 165 DAA $44.5 \%$, with a slight drop to $41.5 \%$ at 180 DAA. Another nuance that can be related to recalcitrance is the reduction in the vacuoles number at $175 \mathrm{DAA}$, in relation to previous periods (Fig. 5c-e). Cell division is also observed in the embryonic axis, which shows that the recalcitrant seed can be germinated immediately after dispersion at 175 DAA (Fig. 5f). It too can be seen from TEM images that cells, in addition to accumulation of reserve compounds (Fig. 6d-f), exhibit c ell wall integrity and organization (Fig. 6a-c). 

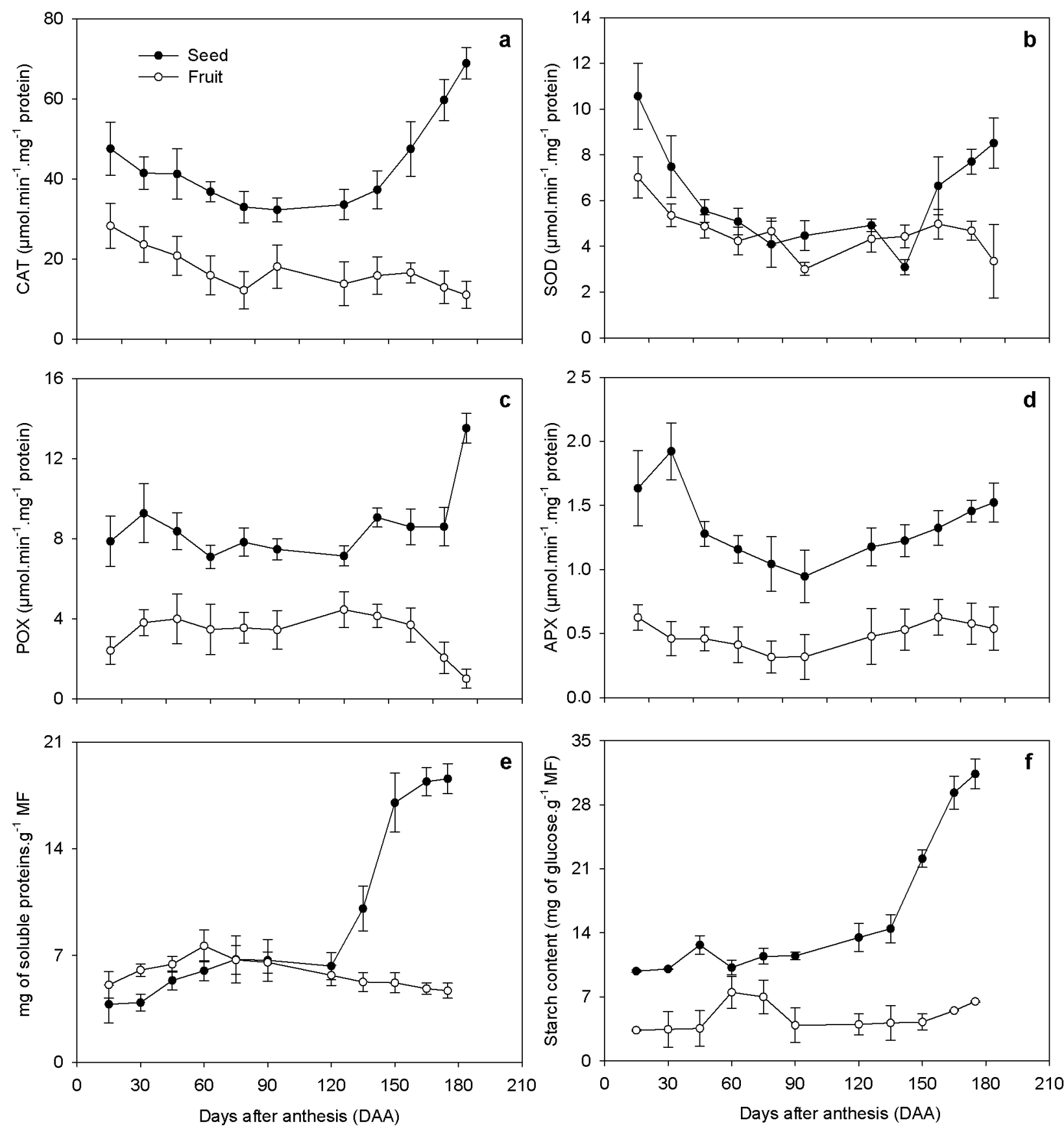

Figure 4 - Oxidative stress enzyme activity of Hevea brasiliensis L., seed, CAT (a), SOD (b), POX (c) and APX (d) in seeds and rubber tree fruit during development, $\mathrm{n}=5 \pm$ standard error and Protein (e), starch content (f), $\mathrm{n}=5 \pm$ standard error.

\section{DISCUSSION}

In many species, seed size reaches its maximum at the beginning of maturation, remaining relatively unchanged until the end of the process (Barbedo et al. 2013). However, in this study, the maximum size was obtained at later stages (150 DAA) (Fig. 1). In Inga striata (Fabaceae), higher values for seed size were found from about 140 up to 155 DAA, in addition to higher increments in dry matter obtained after this period (Mata et al. 2013). 


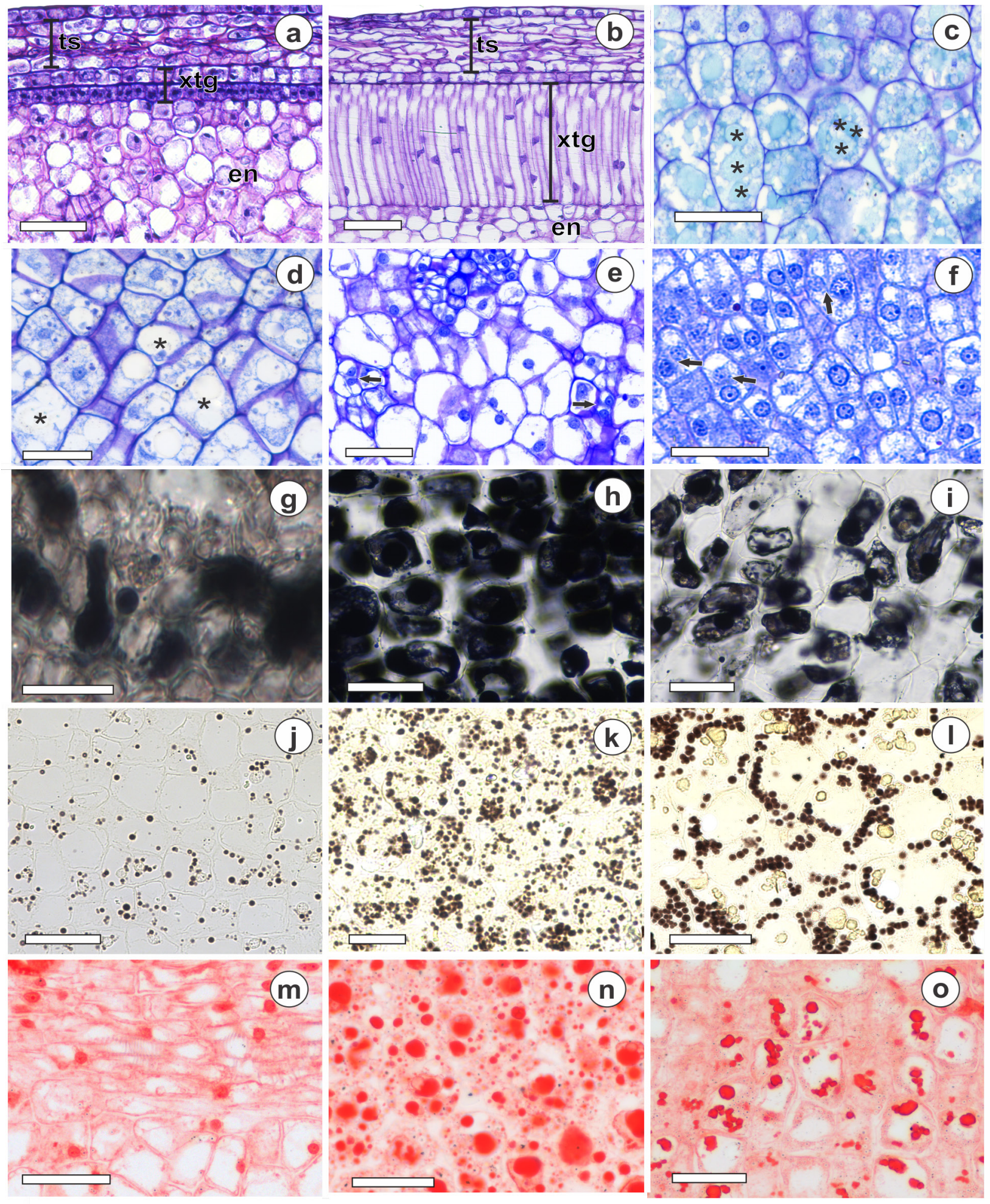

Figure 5 - Transversal section of Hevea brasiliensis L. seeds during development. Seed with 60 DAA (a), with 90 DAA(b); endosperm with 150 DAA (c), 175 DAA (d), 175 DAA (e); Embryonic axis with 175 DAA (f); for lipids content: endosperm with 150 DAA (g), with 165 DAA (h) and with 175 DAA (i); for starch content: endosperm with 150 DAA (j), 165 DAA (k) and 1750 DAA (l) and for protein content: 150 DAA (m), 165 DAA (n) and 175 DAA (o). en, endosperm; xtg, exotegmen, ts, testa Presence of vacuoles. Arrows $=$ evidence of cell division. Bars $=50 \mu \mathrm{m}$. 


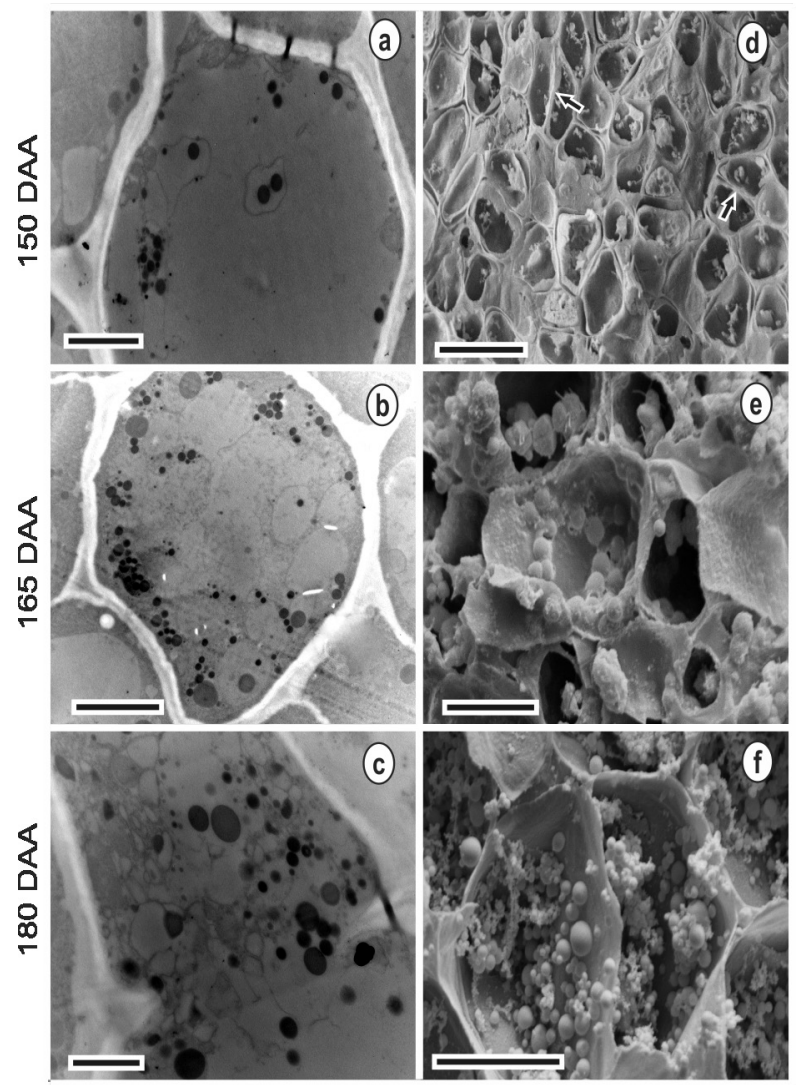

Figure 6 - Section of Hevea brasiliensis L., seeds during development. Transmission electronic microscopy (TEM): a, b and $\mathbf{c}$; Scanning electronic microscopy (SEM): d, e and f. Arrows $=$ evidence of cell division. Bars: $\mathbf{a}=5 \mu \mathrm{m}, \mathbf{b}=2 \mu \mathrm{m}, \mathbf{c}$ $=1 \mu \mathrm{m}$ and $\mathbf{d}, \mathbf{e}, \mathbf{f}=25 \mu \mathrm{m}$.

The maximum values of growth are associated with cell elongation that constitutes the seed structure and comprises the reserves deposition increase, in addition to accommodating the embryo growth, which in the case of rubber tree seeds develops later than the endosperm (Fig. 1).

The reduction in seed and fruit moisture at the end of maturation is related to the end of development. Similar behavior was observed by Moreira (2009) in rubber tree seeds during development, wherein this author found high moisture values, approximately $85 \%$ in the seeds up to 95 days after pollination (DAP), and after this period, a decline until the moisture value reaches about 45 to $50 \%$ at 195 DAP. It is noteworthy that these studies were carried out in different locations, with different climatic variations. In addition, in recalcitrant seeds there is a drop in moisture content, but not as discernable as in orthodox seeds. According to Barbedo et al. (2013), recalcitrant seeds are orthodox seeds that did not complete their ripening and could be dispersed before the end of this process, which could explain the high moisture content with which the rubber tree seeds are dispersed.

Water content (Barbedo et al. 2013) and dry matter percentage (Caccere et al. 2013) are considered good indexes for estimating the seed physiological maturity point (SPMP), even though water content, age or place of origin vary widely among species. Physiological maturity can be characterized by the maximum content of dry mass, which indicates cessation of assimilate translocation to the seed. However, the use of only one or two parameters does not provide sufficient reliability to define the maturity stage of a seed, requiring the use of other factors, such as germination and ESI, amongst others, to give greater reliability.

The acquisition of the germination capacity of some species may occur at the beginning of seed development (Lamarca et al. 2013, Borges et al. 2006), which did not occur in this study. The germination at 175 DAA (before dispersal) and at 180 DAA (after dispersal) was significantly higher than the other evaluated periods $(\mathrm{P}<0.05)$. It is worth mentioning that before 150 DAA, no germination was observed in the seeds collected, even if the reserve substances had already been deposited in large part. Germination occurred only starting at $150 \mathrm{DAA}$, although at a low rate, (only $28 \%$ of germination). The embryos were not fully formed until that date (150 DAA). Embryos were probably in the transition phase from cordate form to torpedo stages with apices and meristematic tissues forming. After 150 DAA, the embryo was in a cotyledonary phase (enlarged cotyledons) that already allowed the germination (Fig. 2). The highest values of emergence and ESI coincided 
with the lowest moisture contents and a higher dry matter percentage (Fig. 1).

This suggests that the seed physiological maturity point (SPMP) of the rubber tree coincides with the highest DM content and the lowest $\mathrm{M}$ of the seeds. Therefore, such parameters can help to identify the SPMP of this species. These data are similar to those found in another study with rubber tree seeds, wherein SPMP was reached at 195 DAP (Bonome et al. 2011), while in this study, it was 175 DAA. The difference in the SPMP estimate among these studies can be attributed to variations in the seed development environment and in genetic variations of the seed itself. Similar results were obtained with Erythrina variegata L. seeds by Matheus et al. (2011) and in Inga striata seeds by Mata et al. (2013).

The efficiency of the DM content and the reduction in MC as SPMP markers is related to biochemical and physiological change, such as accumulation of reserve compounds. Additionally, the reduction in moisture content in the seed favors subsequent expression of genes that control the content of gibberellin (GA) and abscisic acid (ABA), wherein $\mathrm{ABA}$ is related to the expression of maturation compounds (Yan and Chen 2017, Vornam et al. 2011). It may also be associated with other changes where the expression of more intense bands is related to the HRPs expression. This relationship was observed from the 150 DAA (Fig. 3 ), in addition to the signaling for the accumulation of reserve compounds such as starch, proteins and lipids that occurred intensively from 135 DAA (Figs. 4 and 5).

HRPs are related to desiccation tolerance in orthodox species. Nonetheless, they are also found in recalcitrant seeds, wherein they have molecular weights of 46, 35, and $23 \mathrm{kDa}$ (Kalemba and Pukacka 2012, Vornam et al. 2011). Protein expression regulation takes into account environmental factors, the accumulation of heat hours during the development, water loss and rainfall (Kalemba and Pukacka 2012). The higher radiation and lower rainfall observed coincided with the end of maturation (data not shown) and may have influenced the expression of these proteins. Low molecular weight HRPs found in this study (21 to $45 \mathrm{KDa}$ and $60 \mathrm{KDa}$ ) can function as antioxidants and membrane stabilizers, so as to stabilize other proteins during periods of water stress, or as molecular chaperones (Tunnacliffe and Wise 2007). Soares et al. (2015) found consistent bands of $66 \mathrm{KDa}$ protein when studying mature orthodox seeds. This is similar to what we found here in rubber tree seeds, mainly for 175 and 180 DAA.

GAs are associated with a greater synthesis of enzymes such as expansins, favoring the loosening of the endosperm and the tegument, thus, reducing the counterforce exerted by these structures on the embryo and facilitating radicle protrusion (Nonogaki et al. 2010), which enables the seed to acquire germination capacity (Fig. 1).

The EC test provides indirect information about the integrity of cell membranes. Higher EC values in the early stages of development are related to the low integrity of cell membranes, whereas a decrease in these values indicates greater organization and a deposit of reserve material (Pavithra et al. 2014). In this study, an EC reduction was observed in the seed imbibition solution from 150 DAA, wherein the seeds already showed germination, stabilizing at the end of maturation (175 DAA). Similar results were obtained by Pavithra et al. (2014) when evaluating the development of Pongamia pinnata (L.) seeds that exhibited lower EC values coincident with SPMP.

EC reduction, in this case, can be attributed to a higher structuring of the seed tegument with greater lignin and wax deposition (Fig. 1). The larger tegument structure in many cases may be related to color, in general, where the greater the number of layers, the darker is the tegument. Rubber tree seeds at 175 and 180 DAA have a 
darker and stiffer tegument (Fig. 1), probably providing a stronger barrier for water to enter and consequently affecting the EC.

In relation to the high activity of oxidative stress enzymes at the beginning of seed development, this may be related to the high water content (Gomes and Garcia 2013) and the many metabolic reactions associated with histodifferentiation. At the end of maturation, there was again a higher enzyme activity, in this case, related to preparatory events for germination. The observed increase in SOD activity at 135 DAA may reflect higher metabolic activity from that date, and maybe a reflection of the activities of POX, CAT and APX at 120 DAA. The most evident increase of CAT suggests that eventual production of ROS is along the route of hydrogen peroxide formation. Considering the POX activity in auxin catabolism and in the formation of wall components and the demand for hydrogen peroxide as a substrate, it can be inferred that the activity variation of this enzyme occurs at moments in which the seeds' components present a greater synthesis of the wall (Zheng et al. 2015) or differentiation of cell types related to the end of the embryo maturation process or reserves deposition. This is due to an apparent role in processes related to wall formation during seed development wherein POX is involved, since hydrogen peroxide loosens the bonds between plant cell wall components to allow easy access by polysaccharide enzymes and allow their rapid digestion (Zheng et al. 2015), providing cell growth.

Seed development of many recalcitrant species proceeds directly from maturation to germination, missing the dehydration phase. The ROS's can also act as agents favoring germination, acting on the weakening of the endosperm and tegument, and/or also, as protection for the radicle against pathogenic soil microorganisms (Schopfer et al. 2001).

This behavior is easily explained since recalcitrant seeds are apt to germinate soon after their formation. The preparatory events for germination may possibly begin even before dispersal. One such mechanism may be the ROS's production that influences the activity of oxidative stress enzymes. These enzymes showed an increase in activity from $135 \mathrm{DAA}$, indicating a higher ROS production from this date (Fig. 4).

In studies to evaluate oxidative stress enzymes in fruits and pea seeds, Matamoros et al. (2010) observed an increase in SOD activity and stability in APX activity at the end of maturation. These authors associated APX behavior with stabilization of ROS production by this species and decline in water content. In the present study, we observed higher activity of all enzymes evaluated (SOD, APX, POX, CAT) at the end of seed development of the rubber tree. This increase in enzymatic activity was most likely due to the high moisture content and thus to the accelerated metabolism with which the rubber tree seeds are dispersed, and to environmental stress as the high incidence of solar radiation at the end of development. Contrary to what happened in the seeds, we observed a reduced activity of these enzymes in the fruit at the end of maturation, suggesting a reduction in fruit metabolism.

The accumulation of reserve compounds during the development of some seeds occurs mainly in the cotyledons (Borek et al. 2013, Borek and Nuc 2011). This behavior can also be observed for rubber tree seeds mainly in relation to proteins (Figs. 4 and 5h, 1). According to Pavithra et al. (2014), the proteins can be related to the lipid bodies preventing their coalescence by the action of hydrolytic enzymes. It is noted that the pattern of protein accumulation was similar to that of starch and lipids (Figs. 4 and $5)$ in all embryo, cotyledon, embryonic axis and endosperm structures (data not shown).

In addition to this possible protective role, protein accumulation in seeds is associated with maturation by its relation to the synthesis of genetic material and the enzymatic reactions essential to cellular metabolism. These data coincide with those 
reported by Wang et al. (2001), for Olea europaea seeds, and Kesari and Rangan (2010) for Pongamia pinnata seeds, wherein there was an increase in the protein concentration in the last periods of seed development.

Lipids are considered the main reserve of oilseeds such as rubber tree. An increase in lipid content was also reported by Rubio et al. (2013) in Jatropha curcas L. seeds and by Bonome et al. (2011), in rubber tree seeds. In this case, large increases in lipids deposition were observed in the last maturation periods, mainly in the embryonic axis.

The importance of lipids is due to their participation in the cell membrane composition. These compounds are directly related to seed quality because they are a source of energy reserves during germination. Rubber tree seeds are rich in lipids, but their use only occurs after the depletion of reserves that provide energy (sugars) more immediately, such as starch. The lipid use requires greater energy demand, since many metabolic steps are involved. In the glyoxylate cycle, insoluble seed lipids are converted to soluble sugars (sucrose), which are displaced to the points where there is energy demand and cleaved by saccharolytic enzymes and made available for Krebs Cycle (Taiz and Zeiger 2015).

Cellulose and, to a lesser degree, starch are the most abundant compounds in plants, being the main sites of carbon sequestration. There is a great accumulation of starch during rubber tree seed development (Figs. $4 \mathrm{f}$ and $5 \mathrm{j}-1$ ), according to results in the present work. Little change was observed in the fruit, with slight reduction at the end of the development, probably due to the mobilization of the starch favoring seed development (Fig. 4f).

In general, embryos have an initial phase of starch accumulation, which occurs before accumulation of other reserves such as lipids and proteins, followed by reduction in levels of this compound during embryonic development
(Andriotis et al. 2010). However, according to these same authors, a higher starch amount was found in embryos during germination, since in most cases, starch is the main source of carbon during germination and seedling establishment (Krunic et al. 2017, Shaik et al. 2016). In rubber tree seeds, the opposite behavior was observed, with increasing starch accumulation throughout development in both the endosperm and the embryo. This behavior may be related to the recalcitrant character of this species, which initiates the germination process immediately after dispersion. Thus, it is possible that events in preparation for this process begin even before dispersal, as can be observed by the large incidence of dense nuclei and cell division in the embryonic axis of these seeds (Fig. 5c, f), thus affecting the starch concentration at the end of maturation.

Differences in starch accumulation have also been reported in embryos of Brachypodium distachyon (Wolny et al. 2014). According to these authors, differences in starch concentration and accumulation vary with the physiological state of the embryos and the developmental stage. In the present study, there is a great accumulation of this reserve, with no apparent reduction during the end of development, as already mentioned. Associated to this behavior, we observed coalescence of proteins in the final phases (Fig. 5o), favoring, thus, greater protein degradation. A fast decline in protein content along with slow starch degradation in barley grains indicates that the protein may act as an alternative substrate of the respiration (Macgregor and Matsuo 2016). Possibly, at the end of the development, during germination preparative events, starch availability is limited by its slow degradation, and the embryo uses protein breakdown to initiate the germination process, which may be an inherent characteristic of this species under the conditions evaluated.

In association with the accumulation of reserve compounds, some studies have reported 
a series of anatomical adaptations at the end of maturation, mainly in orthodox seeds, in cell membranes and organelles (Moura et al. 2010). Alterations that cause changes in metabolism also occur in recalcitrant seeds, aiming to increase the metabolic efficiency (Caccere et al. 2013, Barbedo et al. 2013). So, in addition to changes in reserve compounds in rubber tree seeds, as mentioned previously (Fig. 5g-o), there was an increase in size vacuoles at 150 and 165 DAA (Fig. 5c, d), which began to occupy a large part of the cellular volume, mainly in the endosperm. This could be considered an adaptation of recalcitrant seeds to maintain high metabolic rates at the end of maturation. Cell division was also observed in the embryonic axis (Fig. 5f), indicating that there is preparation to germination immediately after dispersal. Caccere et al. (2013) also observed an increase in number and size of vacuole, in the cotyledons and embryo axis in Inga seeds.

By SEM scanning analyzes, we also observed cell division in seed development in the endosperm (Fig. 6d), which causes the increase of seeds size (Fig. 5a, b).

Analyzing the initial development pattern and the accumulation of reserve compounds from 135 DAA (Fig. 4) to 175 DAA (Fig. 5), we recognize rubber tree seeds development as three major phases: histodifferentiation (until 75 DAA), cell elongation and expansion (75 to 120 DAA) and maturation (135 to $175 \mathrm{DAA})$. The definition of these phases facilitates the understanding of the biochemical and anatomical changes during rubber tree seed development. As in SEM images, in TEM we can also verify such changes: cell membrane and cell wall integrity, cell wall and mainly the accumulation of reserve compounds (Fig. 6a-c).

Associating all evaluated factors, it is concluded that SPMP of rubber tree seeds evaluated in this study was reached at $175 \mathrm{DAA}$. As there was no significant difference in germination and ESI of seeds between the periods of 175 and 180 DAA, collection of seeds before fruit dehiscence could be an alternative to avoid loss of seed viability. Seeds that enter into contact with the soil are exposed to contamination by pathogenic microorganisms (data not shown) and they are exposed to environmental conditions which could increase the activity of antioxidant enzymes activity, indicating an increase in the ROS production, which over time can lead the seed to deterioration.

In this way, it is possible to conclude that there is a great accumulation of reserve compounds in the rubber tree seeds at the end of maturation.

\section{CONCLUSIONS}

Physiological maturity of rubber tree seeds occurs at $175 \mathrm{DAA}$, and coincides with its maximum vigor.

Higher percentages and germination speed are obtained with seeds harvested at 175 DAA and with dispersed seeds at 180 DAA compared to earlier stages.

At 175 DAA and 180 DAA, there is a greater expression of heat resistant proteins for low molecular weight (smHRP) and greater oxidative stress enzyme activity.

Rubber seeds show evidence of recent cell division at the embryonic axis at the end of maturation, which may be associated with the recalcitrant character of this species.

The accumulation of reserve compounds in rubber tree seeds occurs more intensely in the final stages of maturation.

\section{ACKNOWLEDGMENTS}

The authors would like to thank the Fundação de Amparo à Pesquisa do Estado de Minas Gerais (FAPEMIG) and the Conselho Nacional de Desenvolvimento Científico e Tecnológico (CNPq) for their support.

\section{REFERENCES}

ANDERSON MD, PRASAD TK AND STEWART CR. 1995. Changes in isozyme profiles of catalase, peroxidase, and 
glutathione reductase during acclimation to chilling in mesocotylus of maize seedlings. Plant Physiol 109: 12471257.

BARBEDO CJ, CENTENO DCC AND RIBEIRO RCLF. 2013. Do recalcitrant seeds really exist? Hoehnea 40: 583593.

BEAUCHAMP C AND FRIDOVICH I. 1971. Superoxide dismutase: improved assays and an assay applicable to acrylamide gels. Anal Biochem 44: 276-287.

BONOME LTS, MOREIRA SAF, OLIVEIRA LEM AND SOTERO AJ. 2011. Metabolism of carbohydrates during the development of seeds of the Brazilian rubber tree [Hevea brasiliensis (Willd. Ex Adr. De Juss) Muell.-Arg.]. Acta Physiol Plant 33: 211-219.

BOREK S, GALOR A AND EWELINA-PALUCH E. 2013. Asparagine enhances starch accumulation in developing and germinating lupin seeds. J Plant Growth Regul 32: 471-482.

BOREK S AND NUC K. 2011. Sucrose controls storage lipid breakdown on gene expression level in germinating yellow lupine (Lupinus luteus L.) seeds. J Plant Physiol 168: 1795-1803.

BORGES IF, BARBEDO CJ, RICHTER AA AND FIGUEIREDO-RIBEIRO RCL. 2006. Variations in sugars and cyclitols during development and maturation of seeds of brazil wood (Caesalpiniae chinata Lam., Leguminosae). Braz J of Plant Physiol 18: 475-482.

BRASIL. 2009. Ministério da Agricultura e Reforma Agrária. Regras para análise de sementes. Brasília: Mapa/ACS, 399 p.

CACCERE R, TEIXEIRA SP, CENTENO DC, FIGUEIREDORIBEIRO RCL AND BRAGA MR. 2013. Metabolic and structural changes during early maturation of Inga vera seeds are consistent with the lack of a desiccation phase. $\mathrm{J}$ Plant Physiol 170: 791-800.

CHANCE B AND MAEHLEY AC. 1995. Assay of catalases and peroxidases. Methods Enzymol 2: 764-775.

DEL LONGO OT, GONZÁLEZ A, PASTORI GM AND TRIPPI VS. 1993. Antioxidant defenses under hyperoxygenic and hyperosmotic conditions in leaves of two lines of maize with differential sensitivity to drought. Plant Cell Physiol 34: 1023-1028.

GIANNOPOLITIS CN AND RIES SK. 1977. Superoxide dismutases. Plant Physiol 59: 309-314.

GOMES MP AND GARCIA QS. 2013. Reactive oxygen species and seed germination. Biologia 68(3): 351-357.

HAVIR EA AND MCHALE NA. 1987. Biochemical and developmental characterization of multiple forms of catalase in tobacco leaves. Plant Physiol 84: 450-455.

JOHANSEN DA. 1940. Plant microtechnique. McGraw-Hill Books. New York, 523 p.

KALEMBA EM AND PUKACKA S. 2012. Association of protective proteins with dehydration and desiccation of orthodox and recalcitrant category seeds of three acer genus species. J Plant Growth Regul 31: 351-362.

KARE M AND MISHRA D. 1976. Catalase, peroxidase, and polyphenoloxidase activities during rice leaf senescence. Plant Physiol 57: 315-319.

KESARI V AND RANGAN L. 2010. Development of Pongamia pinnata as an alternative biofuel crop-current status and scope of plantations in India. J Crop Sci Biotechnol 13: 127-137.

KOSHIBA T. 1993. Cytosolic ascorbate peroxidase in seedlings and leaves of maize (Zea mays). Plant Cell Physiol 34: 713-721.

KRUNIC S, SKRYHAN K, MIKKELSEN L, RUZANSKI C, SHAIK SS, KIRK H, PALCIC M AND BLENNOW A. 2017. Non-GMO potato lines with altered starch biosynthesis pathway confers increased-amylose and resistant starch properties. Starch/Stärke 70: 1-13.

LAMARCA EV, PRATAVIERA JS, BORGES IF, DELGADO LF, TEIXEIRA CC, CAMARGO MBP, FARIA JMR AND BARBEDO CJ. 2013. Maturation of Eugenia pyriformis seeds under different hydric and termal conditions. An Acad Bras Cienc 85: 223-233.

MACGREGOR AW AND MATSUO RR. 2016. Starch degradation in endosperm of Barley and Wheat kernels during initials stages of germination. Cereal Chem 59(3): 210-216.

MAGUIRE JD. 1962. Seeds germination-aid selection and evaluation for seedling emergence and vigor. Crop Sci 2: 176-177.

MATA MF, SILVA KB, BRUNO RLA, FELIX LP, MEDEIROS FILHO S AND ALVES EU. 2013. Maturação fisiológica de sementes de ingazeiro (Inga striata) Benth. Semin Agrar 34: 549-566.

MATAMOROS MA, LOSCOS J, DIETZ KJ, APARICIOTEJO PM AND BECANA M. 2010. Function of antioxidant enzymes and metabolites during maturation of pea fruits. J Exp Bot 61: 87-97.

MATHEUS MT, LOPES JC AND CORRÊA NB. 2011. Maturação fisiológica de sementes de Erythrina variegata L. Ciênc Florest 21: 619-627.

MOREIRA A, MORAES LAC AND FAGERIA NK. 2009. Potential of rubber plantations for environmental conservation in the Amazon Region. Biorem Biodiv Bioavail 3: 1-5.

MOURA EF, VENTRELLA MC AND MOTOIKE SY. 2010. Anatomy, histochemistry and ultrastructure of seed and somatic embryo of Acrocomia aculeate (Arecaceae). Sci Agric 67: 399-407.

NAKANO Y AND ASADA K. 1981. Hydrogen peroxide is scavenged by ascorbate specific peroxidase in spinach chloroplasts. Plant Cell Physiol 22: 867-880.

NONOGAKI H, BASSEL GW AND BEWLEY JD. 2010. Germination - Still a mystery. Plant Sci 179: 574-581. 
O'BRIEN TP AND MCCULLY ME. 1981. The study of plant structure: principles and selected methods. Termarcarphy Pty. Australia: Melbourne, 352 p.

PAVITHRA HR, GOWDA B AND SHIVANNA MB. 2014. Biochemical changes in the composition of developing seeds of Pongamia pinnata (L.) Pierre. Ind Crops Prod 53: 199-208.

PEARSE AGE. 1972. Histochemistry. Theoretical and applied, $3^{\text {rd }}$ ed., vol. 1, p. 1-759 (1968); J \& A Churchill: London 2: $761-1518$.

PEIXOTO PHP, CAMBRAIA J, SANT'ANA R, MOSQUIM PR AND MOREIRA MA. 1999. Aluminum effects on lipid peroxidation and on activities of enzymes of oxidative metabolism in sorghum. Rev Bras Fisiol Veg 11: 137-143.

RUBIO F, MENEGHEL AP, GOMES LFS AND MALAVASI MM. 2013. Estádios de maturação do fruto no desempenho germinativo e teor de óleo de sementes de Jatropha curcas Linn. Semin, Ciênc Agrár 34: 663-668.

SCHOPFER P, PLACHY C AND FRAHRY G. 2001. Release of reactive oxygen intermediates (superoxide radicals, hydrogen peroxide, and hydroxyl radicals) and peroxidase in germinating radish seeds controlled by light, gibberellin, and abscisic acid. Plant Physiol 125: 1591-1602.

SHAIK SS, OBATA T, HEBELSTRUP KH, SCHWAHN K, FERNIE AR, MATEIU RV AND BLENNOW A. 2016. Starch granule re-structuring by starch branching enzyme and glucan water dikinase modulation affects caryopsis physiology and metabolism. PLoS ONE 11: 1-21.

SILVA DJ. 1990. Análise de alimentos - métodos químicos e biológicos. Viçosa, MG: Universidade Federal de Viçosa, $165 \mathrm{p}$.

SOARES GCM, DIAS DCFS, FARIA JMR AND BORGES EEL. 2015. Physiological and biochemical changes during the loss of desiccation tolerance in germinating Adenanthera pavonina L. seeds. An Acad Bras Cienc 87: 2001-2011.

TAIZ L, ZEIGER E, MØLLER IM AND MURPHY A. 2015. Plant Physiology and Development, $6^{\text {th }}$ ed., Sinauer Associates, Incorporated, Sunderland, Massachusetts, 761 p.

TUNNACLIFFE A AND WISE MJ. 2007. The continuing conundrum of the LEA proteins. Naturwissenschaften 94: 791-812.

VORNAM B, GAILING O, DERORY J, PLOMION C, KREMER A AND FINKELDEY R. 2011. Characterisation and natural variation of a dehydrin gene in Quercus petraea (Matt.) Liebl. Plant Biol 13: 881-887.

WALTERS C, BERJAK P, PAMMENTER N, KENNEDY K AND RAVEN P. 2013. Preservation of recalcitrant seeds. Science 339: 915-916.

WANG W, DE-DIOS-ALCHE J, CASTRO A AND RODRIGUEZ-GARCIA M. 2001. Characterization of seed storage proteins and their synthesis during seed development in Olea europaea. Int J Dev Biol 45: 63-64.

WOLNY E, BRASZEWSKA-ZALEWSKA A AND HASTEROK R. 2014. Spatial distribution of epigenetic modifications in Brachypodium distachyon embryos during seed maturation and germination. PLoS ONE 9: 1-10.

YAN A AND CHEN Z. 2017. The pivotal role of abscisic acid signaling during transition from seed maturation to germination. Plant Cell 36: 689-703.

ZHENG L ET AL. 2015. Transcriptomic analysis reveals importance of ROS and phytohormones in response to short-term salinity stress in Populus tomentosa. Front Plant Sci 6: 1-15. 